$\langle$ 症例〉

\section{嚥下内視鏡検査による 嚥下評価の試み}

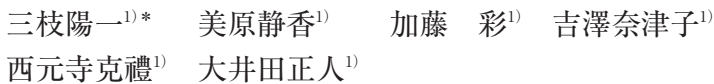

${ }^{1)} \mathrm{JCHO}$ 相模野病院/消化器病センター

*Corresponding author : ysaegusas@yahoo.co.jp

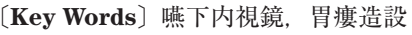

\section{はじめに}

わが国は超高齢化社会を迎え, 脳梗塞, 悪性腫瘍, 加 齢変化により燕下障害の症例が増加し，75歳以上の症

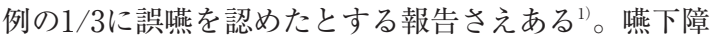
害が重度の場合は, 胃㾇造設の適応となる。PEG (percutaneous endoscopic gastrostomy)の適応を考える 上で誤嚥の病状を把握できる燕下内視鏡検查 $(\mathrm{VE}$ ： videoendoscopic evaluation of swallowing) は必要で ある。また消化器内視鏡医によりPEG造設が行われる のが一般的であり, 誤嚥状態を把握することも必要で ある。

さらに診療報酬改定によって胃瘦造設前の嚥下評価 を積極的に行う機会が増えている。嚥下評価は耳鼻科 で多く行われているが，耳鼻科医が不在の中小規模病 院では, 嬹下評価を行う設備不足やスタッフの知識不 足により, 実際のところ嚥下評価は行われていないこ とが多い。よって鱟下評価が十分に行われていない状 態で，消化器内視鏡医により PEG造設となることが多 い。当院ではVEを導入し, 消化器内視鏡医が嚥下評価 を行っている。その評価法について報告する。

\section{方 法}

四燕下評価は，嚥下障害が疑われる症例ではベッドサ イドでVEを使用して行う。当院では耳鼻科用のENT30S (町田製作所製)を使用している。全長 $534 \mathrm{~mm}$ で先 端部 $4.2 \mathrm{~mm}$ の太さと，比較的小さく移動が容易である ことから移動困難な患者には, ベッドサイドで検查を 施行する。径が細い内視鏡で違和感がでないため, 與 下に影響する鼻腔，咽頭麻酔をせずに経鼻的に内視鏡 を挿入できる。液体，ゼリーを経口的に摂取させ，燕 下している喉頭を内視鏡的に観察し，嚥下の状態を評 価していく。燕下の状態を客観的に評価するため，兵 頭スコアを使用して, 重症度に応じてPEGの適応を検 討する (Table 1) ${ }^{2)}$ 。
Table 1 Scoring proposed for endoscopic swallowing evaluation.

<兵頭スコア $>$

- 喉頭蓋谷や梨状陥凹の唾液貯留 $0 \sim 3$ 点

・咳反射・声門閉鎖反射の惹起 $\quad 0 \sim 3$ 点

・嚥下反射の惹起性 $0 \sim 3$ 点

・咽頭のクリアランス $\quad 0 \sim 3$ 点

- 4 点以下：経口摂取は問題なし

・5 8 点: 誤嚥のリスクあり, 対応が必要

. 9 点以上 : 経口摂取は不可能

\section{症 例}

【症例 1】

患者：84歳，男性。老人介護施設入所中。日中をほ とんどベッドで過ごしていた。食事もベッドで全强食 を食べていた。最近, 食事の際にむせ込みがあり, PEG 造設依頼で当院に転院となった。PEG造設検討のVE検 査を行った。

結果：VEでは喉頭蓋を 6 時方向にして評価してい く。ゼリーを摂取させて評価したが，嚥下反射は速や かだった。ゼリーはすべて嚥下され，残存はなく，嚥 下後の咽頭クリアランスもよく, 唾液の貯留もなかっ た。兵頭スコアは 0 点で, 嚥下可能でPEG造設は必要 なしと判断した。食形態の工夫や讌下リハビリを実施 して食事の摂取が可能となった $($ Color 1)。

【症例 2 】

患者：79歳，女性。脳梗塞を発症して入院。発症後 は嚥下障害があり，経鼻胃管が抻入されている。在宅 での栄養管理を希望され, $\mathrm{PEG}$ 造設の依頼を受け, $\mathrm{PEG}$ 造設検討のVE検査を行った。

結果:ゼリーを摂取させVEで観察したが，嚥下反射 が遅く, ゼリーの一部は気管支に落ち, 誤嚥を認めた。 ゼリーは咽頭喉頭内に残り, 嚥下後のクリアランスも 悪く, 唾液なども貯留していた $($ Color 2)。兵頭スコア は 9 点で, 現時点で嚥下不可能と判断LPEG造設を 行った。

\section{考 察}

PEG造設の多くは消化器内視鏡医によって行われる が, 嚥下評価について習熟している消化器内視鏡医は 少ない。そのため食事形態の工夫やリハビリテーショ ンで輿下可能な症例が, 適切な嚥下評価を行わないま ま不必要なPEG造設に至る場合もある。このためPEG 造設を施行する医師は造設前に嚥下評価を行い，その 適応を考える必要がある。同時にPEG抜去を検討をす る際にも, PEG造設後の栄養状態改善による嚥下機能 回復についても，嚥下評価を行う必要がある。 
嚥下評価が中小病院で行われない原因としては，嬩 下機能評価が行える設備がないこと，耳鼻科医が不在 で醼下評価のトレーニングを受けている医師がいない などの原因が考えられる。その問題解決の 1 つとして, PEG在宅医療研究会主催の嚥下評価研修会への参加が ある。VEを実臨床で使用してトレーニングしている が，消化器内視鏡医であれば，内視鏡検査に習熟して いるメリットを活かすことで, VE手技も容易に習得可 能と考える。

2014年度より PEG造設の診療報酬は10,070点から 6,070点と大幅に減点された ${ }^{3)}$ 。 し LVE，上部消化管 内視鏡検査を行って胃瘦造設すると 9,710 点となり, 以 前とほぼ同額の医業収入を得ることができる。医療経 済上もVEの必要性は増していると考える。

今後の高齢化社会では曣下障害による患者が増えて いく可能性が高いため, VE導入に備え, 消化器内視鏡 医としても積極的にVEを行えるスキルを取得してい く必要がある。

\section{文 献}

1 ）西山耕一郎，永井浩巳，其井大祐，他：一診療所における嚥 下障害への取り組み。日気食会報, $58: 384-391,2007$.

2 ）兵頭政光, 西窪加緒里, 弘瀬かほり：嚥下内視鏡検查におけ るスコア評価基準(試案)の作成とその臨床意義. 日耳鼻会報, $113: 670-678,2010$

3 ) 飯島正平:「平成 26 年度診療報酬改定」概要; 栄養管理を中 心に. Nutrition Care, 7:375-382, 2014

$$
\text { 〈カラーはp. } 5 \text { に掲載〉 }
$$

\section{Videoendoscopic evaluation of swallowing}

$\begin{array}{ll}\text { Yoichi Saegusa }^{1) *} & \text { Shizuka Mihara } \\ \text { Aya Kato }^{1)} & \text { Natsuko Yoshizawa } \\ \text { Katsunori Saigenji1) }^{1)} & \text { Masato Oida }\end{array}$

The growth of the elderly population has led to an increased prevalence of dysphagia. Percutaneous endoscopic gastrostomy (PEG) performed by gastroendoscopists is indicated for severe dysphagia. The indications for PEG must be based on an appropriate evaluation of swallowing, now more important because of the revised medical payment system. Swallowing function is often evaluated by otolaryngologists, but many small and medium-sized hospitals have no otolaryngologists. In our hospital, gastroendoscopists use videoendoscopic evaluation of swallowing (VE) to evaluate swallowing function.

VE was performed in patients with suspected dysphagia. VE images were evaluated using Hyodo's scoring system to determine indications for PEG

Accurate swallowing evaluations enabled appropriate indications for PGE to be determined. The remuneration for PEG has decreased from 10,070 to 6,070 points. However, when PEG was performed after VE and esophagogastroduodenoscopy, the remuneration increased to 9,710 points, nearly equivalent to the previous value.

Gastroendoscopists are proficient in endoscopic examinations and can easily master VE techniques. VE is useful for determining the indications for PEG and may be necessary from the viewpoint of healthcare economics. Gastroenterologists should evaluate swallowing function.

1) Digestive Disease Center, Japan Community Health Care Organization Sagamino Hospital

*Corresponding author : ysaegusas@yahoo.co.jp 